\title{
Trainee Teachers' Perceptions of Online Teaching During Field Experience with Young Children
}

\author{
Laila Mohebi $^{1}$ (iD $\cdot$ Lawrence Meda $^{1}$ (D) \\ Accepted: 23 June 2021 / Published online: 14 July 2021 \\ (c) The Author(s), under exclusive licence to Springer Nature B.V. 2021
}

\begin{abstract}
The global pandemic of COVID-19 forced trainee teachers from the United Arab Emirates to have virtual field experiences in the field of early childhood education. The various stakeholders, young children, families, preservice teachers, and university faculty hold different perceptions of online teaching formats. The purpose of this study was to examine the perceptions of trainee teachers and faculty supervisors about online field experiences with young children. The study was done using a qualitative case study within an interpretivist paradigm. Twelve internship students and five supervisors were purposively selected to complete open-ended questionnaires about virtual field experiences. Three themes emerged from the data: (1) integrating technology into lesson planning, (2) meeting challenges to classroom management, and (3) expanding the repertoire of teaching strategies. It is concluded that the virtual field experience was a milestone of achievement for trainee teachers, in terms of the preparation it provided to implement the country's plan of integrating technology in the curriculum.
\end{abstract}

Keywords Trainee teachers · Online teaching $\cdot$ Virtual field experience $\cdot$ Technology integration $\cdot$ COVID-19

\section{Introduction}

Providing quality education is part of the main national agenda of the United Arab Emirates (UAE) (National Agenda, 2018). One of the strategies for attaining this national agenda is by improving the provision of trainee teacher programmes, as this is the foundation for enhancing the education system. It goes without saying that teacher education programmes play a significant role in training qualified and competent future teachers for the next generation. Therefore, the effective and proper training of a trainee teacher is very important. Gürkan, (2018) states that there are many aspects to consider regarding teacher training programmes, from teaching learning theories, to field experience needed. Considering the current situation where the education sector is affected by the Coronavirus (COVID19) pandemic, many teacher training institutions had to let their trainee teachers complete field experience online. The

Laila Mohebi

laila.mohebi@zu.ac.ae

Lawrence Meda

lawrence.Meda@zu.ac.ae

1 College of Education, Zayed University, P.O. Box 19282, Dubai, United Arab Emirates university under study had all its students complete their field experiences online, as a preventative measure to reduce the spread of COVID-19. The purpose of this study was to examine the perceptions of trainee teachers and faculty supervisors about online field experiences with young children. The paper begins by presenting a review of the literature. This is followed by a description of self-perception theory, which is a theoretical framework guiding this study. Then the context of the study is presented, followed by the methodology, results, and discussion. The paper ends with a succinct conclusion.

\section{Review of Literature \\ Importance of Technology Integration}

The global pandemic of COVID-19 has forced many academics in different universities to integrate technology into the curriculum more than before. Technology integration is inevitable in the current educational environment, as it enhances the teaching and learning process and increases teacher knowledge and skills needed in the twenty-first century (Shiburi, 2021). Technology integration is consequential as it has a positive impact on student achievement, 
attitudes, and behaviour (Mohebi, 2018). Brown, (2017) concurs that technology integration has positive effects as it allows students to develop greater cognitive and analytical skills. Such skills enable trainee teachers to conduct successful online field experiences.

The ability of trainee teachers to properly integrate technology during field experience is dependent on experiences they had in their college or university during their preparation years. This is reflected by Mohebi (2018) who argues that there is a need for instructors to use a mixture of various technological instructional strategies in order to help trainee teachers to build the capacity to embed technology meaningfully in their teaching. Thus, teacher training institutions ought to pay more attention to various instructional approaches and improve on technology integration. Konca et al., (2016) conducted a study to understand the attitude of teachers towards integrating technology in their teaching. Their study focused on kindergarten teachers who graduated from face-to-face universities and teachers who graduated from online universities. Their results showed that face-toface graduates had a more positive attitude towards technology integration than the online graduates, because of the quality of in-service training they received.

\section{Online Learning}

Online teaching and learning has been adopted in settings ranging from kindergarten to Grade 12 (K-12) to higher education institutions (HEI) due to the COVID-19 pandemic. Kim, (2020) defines online learning as "an educational process which takes place over the internet as a form of distance education" (p. 145). Numerous studies highlight different aspects of online classrooms. Fedynich (2013) states that attractive characteristics of the online classroom include the ease of participation, flexibility, and convenience. Ersin et al., (2020) and Fiock (2020) contend that online learning is ideal, as it boosts teachers' competences and readiness to implement inclusive digital pedagogical approaches. Albrahim (2020) identifies a set of skills needed to teach online courses. She grouped these into six categories: (a) pedagogical skills, (b) content skills, (c) design skills, (d) technological skills, (e) management and institutional skills, and (f) social and communication skills. These skills can be adopted by trainee teachers in delivering quality age appropriate content. In addition, communication skills are needed for effective explanation of content. Thus, exposing trainee teachers to online learning encourages them to integrate technology in their teaching practice (Hixon \& So, 2009) and affords them an opportunity to have hands-on virtual experiences (Hojeij \& Baroudi, 2021). This is why Ak and Gökdaş (2021) recommend that all trainee teachers should be afforded opportunities to complete virtual field experiences as it helps them to gain knowledge and skills needed to teach effectively in online settings. Even when the current global pandemic of COVID-19 is over, online teaching is likely to continue as "many schools are headed towards complete online modality or blended learning modality in instruction" (Cahapay, 2020, p. 3).

\section{Advantages and Disadvantages of Online Teaching}

Leonard and Guha, (2001) establish that technology integration is a challenging task because of the extrinsic and intrinsic barriers. The extrinsic factors include "lack of access to computers and software, insufficient time to plan instruction and inadequate technical and administrative support, while intrinsic factors include beliefs about teaching, beliefs about computers, established classroom practices and unwillingness to change" (Leonard \& Guha, 2001, p. 56). As part of extrinsic factors, there is less physical activity by students in online learning. That is a disadvantage as Fedynich (2013) argues that through the tactile/kinesthetic approach, students learn and perform better when they move, do, and touch. It is hard for children in early childhood education to learn without play, let alone movement, and for trainee teachers to teach effectively. Kim, (2020) concurs that one of the greatest disadvantages of online learning is that there is limited interaction between trainee teachers and students and when it comes to educating young learners, there is a need for adult supervision which might be a problem for working parents and guardians.

Lestiyanawati and Widyantoro, (2020) conducted a study during the COVID-19 lockdown in 2020 and found that lack of parental support and lack of access to the internet were the main challenges experienced. Moyo, (2020) reported from the Zimbabwean context that virtual field experiences could not be attained as the country did not have sufficient internet coverage to allow remote teaching and learning to occur in schools. Lack of student engagement is another disadvantage of online learning. Cruickshank et al., (2021) argue, from the Australian context that teachers had a challenge when it comes to engaging students online. In Romania, early childhood trainee teachers faced challenges related to delivering content online using interactive means (Miulesco, 2020). This led Valente, (2020) to conclude that online lessons lack interaction and are more passive than face-toface lessons. However, York, (2020) suggests using simple techniques to increase interactivity in class. This can be done by using different online activities and games for children to play. There is a need for trainee teachers to learn more about online teaching and to work with other key stakeholders who include school mentor teachers and administrators, university supervisors and learners. A collaborative working relationship helps trainee teachers gain various pedagogical skills which are relevant to online settings. Rasmitadila, (2020) postulate that Indonesia's success in adopting online 
learning during the pandemic was due to a collaborative working relationship among key stakeholders including teachers, parents, community and the government.

\section{Varying Teaching Activities and Class Management}

Online teaching requires a lot of creativity in order to engage children in early childhood. Kim, (2020) postulates that there is a need for instructors to think deeply about how to design developmentally appropriate practices where children can participate in a variety of hands-on experiences online. In support of that, Lathifah et al., (2020) provide a list of suggestions to support online teaching. They suggested that recorded videos can help if the face-to-face connection is cut and add that the recording must frame the face to give a genuine feeling of presence. The researchers also advised to have short videos which do not exceed $10 \mathrm{~min}$ and to have lessons which are interactive in order to promote critical thinking among learners. This challenges trainee teachers to use different online platforms to maximise young learners' learning experiences. Using online chats, video conferencing, online games, and interactive cloud-based apps like Google Docs can provide a better online learning experience for learners (Lestiyanawati \& Widyantoro, 2020). Lathifah et al., (2020) concur that the use of different apps, videos, pictures and audio help when teaching online. When different teaching activities are used and children are excited about online learning, it makes class management easier and allows effective learning to take place.

It is important to note that managing online classes with children in early childhood requires parental involvement. Lathifah et al., (2020) explored class management practices in online learning and found that teachers received extra help from parents. Dong et al., (2020) argue that the majority of Chinese parents who participated in a survey disliked online learning in early childhood as it required them to provide more support to their children. It is important for teacher training institutions to teach trainee teachers how to manage classes in online settings (Gokuladas \& Sam, 2020). Safitri et al., (2020) argue that classroom and curriculum management strategies are tanatamount to effective teaching and learning in early childhood learning. If young children cannot be controlled during online learning they become disruptive and they will not be able to concentrate when a teacher is teaching (Kim, 2020).

\section{Theoretical Framework}

The theoretical framework guiding this study is the selfperception theory, which was developed by Daryl J. Bem in 1972. The theory claims that we become more aware of our thoughts and behaviours once we evaluate the circumstances surrounding these. Individuals rely on their behaviours and the circumstances in which they (behaviours) occur to understand their inner states such as beliefs and attitudes. Mohebi and Bailey, (2020, p. 3) assert that "self-perception theory simply claims that people become aware of themselves by observing their behaviors."

Self-perception theory has been selected for this study as it can help researchers understand trainee teachers' perceptions of their online teaching experiences during internship. Chai et al., (2017) postulate that understanding students' perceptions of learning with technology can help in improving educational programmes. A number of studies were conducted using self-perception theory. Lui et al., (2006) conducted a study to understand why students blog. They collected data from third year computing students and their findings indicated that "mandatory use of weblogs in a course can gradually cultivate educationally sound perceptions in students, despite the observed misuse" (p. 233). In short, they assert that students' perceptions are vital in promoting successful adoption of technology in education. They further assert that students should interact with technological application to improve their acceptance of technology and learning.

\section{Context of the Study}

The research was conducted at a federal university's College of Education in the UAE. The college prepares trainee teachers to teach in early childhood institutions. The field experience programme model adopted by the college consists of four cumulative levels: Practicum 1, Practicum 2, Practicum 3 and Internship. These courses run for a semester which consists of three and half months. During Practicum 1, trainee teachers observe their mentor teachers teaching in early childhood centres located in public or private schools. They go for six visits in alternating weeks, during the course of the semester. In Practicum 2, trainee teachers go for seven visits in alternating weeks during the course of the semester. They observe their mentor teachers and also begin to conduct mini lessons and read aloud sessions. In Practicum 3, trainee teachers complete ten full day placements in an early years classroom where they assist, instruct mini-lessons and begin to teach whole class lessons. Practicums 1-3 occur every Tuesday only. Internship occurs on every school day for ten consutive weeks and trainee teachers will be expected to assume a more significant teacher role as they will be teaching full lessons. Internship students also engage in learning by conducting action research. This study focused on internship students who completed their field experience online. Each internship student was allocated a school mentor and a university supervisor. A university supervisor 
observed internship students' teaching online and provided feedback on the lesson afterwards.

\section{Methodology}

The study was conducted using a qualitative approach and its paradigmatic position is interpretive. A qualitative approach was selected, as it allowed researchers to collect rich textual data (Creswell \& Poth, 2018) about trainee teachers' perceptions of virtual field experiences. An interpretive paradigm was selected as it is compatible with a qualitative approach. Lapan et al. (2012) argue that every qualitative research design has an interpretive aspect which uncovers participants' views. An interpretive paradigm, like a qualitative approach, allows researchers to let participants express their views and to interpret textual data. The study was done as an exploratory case study of a federal university in the UAE. Researchers chose their university's teacher training programme as the case for the study. A case study was chosen as it enabled researchers to make an in-depth investigation of the phenomenon (Yin, 2018).

Purposive sampling which is characterised by deliberate targeting of information rich respondents, was used to select participants. The sampling technique was selected as it is commonly used in a qualitative research and the selected sample satisfied the study's purpose of examining the perceptions of trainee teachers and faculty supervisors. Cohen et al. (2017) argue that purposive sampling is compatible with a qualitative approach and it enables researchers to select information-rich participants.

A total of 17 participants, consisting of five university supervisors and 12 trainee teachers who were on internship, were selected. Internship students were selected as they had the longest period of teaching online in schools, compared to other students in Practicums 1, 2 and 3. Supervisors were selected to participate in the study as they guided and supervised internship students during their virtual field experience. Each supervisor was allocated six internship students. Every student was evaluated twice by the supervisor during the course of the internship. Supervisors were non-participant observers who completed a lesson observation evaluation form. Supervisors evaluated trainee teachers' plans for the lesson (learning outcomes, teaching and learning resources), teaching styles, content knowledge, ability to differentiate instruction, assessment, and the use of technology. After each lesson observation, the supervisor would meet with the student to provide feedback.

Data was collected using open-ended questionnaires. This data collection tool was selected, as it enabled participants to provide rich textual data about the online field experiences. Data was analysed using content analysis. Two researchers analysed the data manually by first organising it, and then categorising it into many different codes. The researchers met several times to discuss the data and agree on the categories and codes. This was done to ensure consistency of coding (Creswell, 2012). The codes were later collapsed into three main themes. The researchers moved from inductive to deductive in order to determine a final set of themes and their corresponding sub-themes as shown on Table 1.

Each of the three themes was discussed in detail in the findings section. The data analysis pattern is consistent with Creswell's (2012) view of using content analysis within a qualitative approach where researchers organise data, segment or categorise it according to different codes, and generate specific themes out of the codes. Ethical issues were considered by obtaining an ethical clearance certificate from the university. The purpose of the study was explained to all participants. Participation was voluntary and participants were allowed to withdraw from the study at any point in time.

\section{Results}

Three key themes have emerged from the data which was collected from internship students and their supervisors. These are: (1) Integrating technology into lesson planning, (2) Meeting challenges to classroom management, and (3) Expanding the repertoire of teaching strategies. Each of the themes is described in detail and participants' voices are provided to substantiate the information.

Table 1 Themes and sub-themes

\begin{tabular}{lc}
\hline Themes & Sub-themes \\
\hline Integrating technology into lesson planning & $\begin{array}{c}\text { Adopting new technology - the country's digital plan-innovative ways of using } \\
\text { technology - availability of various digital tools }\end{array}$ \\
$\begin{array}{l}\text { Meeting challenges to classroom management } \\
\text { Varying teaching strategies }\end{array}$ & Managing a class in online learning - clear rules and instructions in online learning \\
\hline
\end{tabular}




\section{Integrating Technology into Lesson Planning}

Prior to the COVID-19 pandemic, the UAE planned to ensure that all teachers integrate technology in teaching. The virtual field experience in which trainee teachers participated, provided a milestone of achievement towards preparing for the implementation of the country's integration of technology in education. All 17 participants (12 trainee teachers and five supervisors) unanimously agreed that virtual field experience helped them to achieve the technology integration plan. A supervisor said trainee teachers "had rich opportunity to adapt to the UAE teaching methods and participate with the schools to find solutions to enable young learners to learn and provide them with distance learning experiences." Similarly, another supervisor said "students got to practice proper tech [technology] integration in teaching. Students got to use new websites and platforms." Supervisors viewed online teaching as inevitable, not only because of the current global pandemic of COVID-19, but also because of the digital era in which we live; one where the UAE wants trainee teachers need to be fully prepared to integrate technology in their teaching. A supervisor supported this view saying, "with an increasing number of K-12 students learning online in the UAE schools and in blended learning environments, universities must prepare future educators to teach in virtual environments including clinical practice." The same supervisor went on to say that in order "to develop skills in online pedagogy, teacher education programmes need to expand their current practices and focus on preparing trainee teachers to teach online." The opportunity to do virtual field experience helped students to learn more about technology integration. This aligns with the UAE's digital plan.

Students concurred that the virtual field experience was an opportunity for them to learn a lot about technology integration in the teaching of young children. The following excerpts from trainee teachers support this view:

Distance teaching and management skills have become essential for the teacher, I learned how to use technology better and create a positive learning and interactive environment.

Teaching students online was a very unique experience for me. Using new ways and strategies to teach children certain concepts was very interesting for me. Each part of these virtual classes was different than their face-to-face classes which shows me how I can teach them in many different ways. Distance learning or online learning is one of the most important aspects that we implemented this year. We can say that COVID-19 is a challenge, but I learned many different areas in online learning.
I learned that students need encouragement to learn. So, encouraging them through motivational words is important, using creative methods for students when teaching to attract students' attention, and children need things that make them have fun when learning so that they are not bored. In general, teaching children is fun because it makes teachers become creative people who try to discover the best ways to get students excited about the lesson.

Teaching children online helped me to learn more about teams [Microsoft Teams]. Also, I learned how to manage students online and how to make them all participate in the class. I learned how to know if the child did not understand and how I help him to understand.

Trainee teachers learned a lot from their virtual field experiences. This was supported by their supervisors, who viewed students' experiences as an opportunity for them to be creative and innovative. A supervisor said trainee teachers had "new and innovative experiences which not everybody can have. Students started thinking outside the box to create groups for activities in the classroom. They started being more creative in designing and creating PowerPoints." Another supervisor said, "I believe the teacher candidates are easier to adapt [to] new applications in terms of using them creatively and integrate them into their lesson plan outcomes."

Trainee teachers learned, during their virtual field experiences, what they could have learned in a face-to-face environment, which includes lesson preparation and maintaining a collaborative relationship with parents. Trainee teachers focused on developing and maintaining healthy relationship with parents in order to provide quality learning experiences for their children. This was supported by a student who said:

I learned how to organise a lesson, and how to provide feedback in a way that helps the students. I learned that I should have back up plans for lessons because in an online setting, technical issues are bound to happen. I learned about the importance of maintaining a relationship between parents and students.

Some trainee teachers learned creative ways of enhancing young children's learning experiences online. One trainee teacher said:

I used the chat to ensure that the students are attentive and understanding the concept. Based on my experience, the students enjoyed typing in the chat and using the emojis and that helped maintain their attention. Sometimes I would flip the classroom and ask a student to read/explain. I used show-and-tell. In an attempt to make students comfortable with online participation, I asked them to show us objects from their surroundings that start with the letter that they 
were learning about. I ensured the students' participation by capturing their attention. Instead of allowing everyone to answer, I would call out names. This way, students would stay attentive because they would not know when their names would be called out. Another way to keep the students' attention was through the lesson. The lessons were designed based on the students' interests.

Participants made reference to teaching approaches which were purely student-centred. Even in terms of planning, trainee teachers ensured that they incorporated interactive activities for children to do. This was confirmed by a trainee teacher who said she was "planning lessons with the goal of making them engaging and interactive. In my lessons, my goal was always to ensure that students are the ones that participate more and are the ones that drive the conversation." Trainee teachers learned that interaction is indispensable in an online class. That is why they learned how to use different technologies in order to enhance their teaching experiences online. Similarly, some supervisors were motivated to take professional development courses related to online teaching in order to enhance their abilities to teach effectively and support trainee teachers better. A supervisor said:

It forced me to take some training courses about how to teach and promote student engagement in online learning. I would not have taken these courses if it was not because of wanting to learn more about teaching with technology in order to support my students in Practicum 2 and Internship.

Another supervisor said: "I took a course about teaching online for three months and I was awarded a certificate as a Certified Online Instructor. The experience of taking that course helped me to support trainee students who were doing internship."

\section{Meeting Challenges to Classroom Management}

Class management emerged as one of the themes in the data. All participants reiterated the importance of class management as an essential starting point for successful online teaching and learning in early childhood. Trainee teachers acknowledged the importance of class management, as it is tantamount to the success of teaching young children online, and reflected on the ways they developed class management skills in online learning. One trainee teacher provided comprehensive details about class management saying:

I have learned two techniques that are useful for classroom management, these are setting rules and interacting with parents. First, establishing rules at the beginning of each class is important for students to follow during class time. Also, by setting class rules, the teacher allows students to know her expectations and what she expects from them. Second, interacting with parents is the best thing teachers can do when it comes to managing classes. These daily meetings between students, their parents and the teacher allow to organise the classroom. It also gives parents a good idea of their children's personalities, their strengths, what concerns them and what they need to improve. I think I will learn a lot of classroom management strategies in the coming days.

When young children are guided effectively online, it makes it possible for teaching and learning to take place. This is why trainee teachers developed rules and enforced them in their online classes. One trainee teacher said: "At the beginning of each class, I remind students of the rules. I ask all students to mute their microphones if it is not their turn to answer."

Some trainee teachers reflected on class management saying:

I have many effective experiences in teaching students online. For example, now I am able to manage student behaviour. I also learnt how to organise time according to activities. I learned how to evaluate student success through activities.

My experience was something unique, new and challenging. Children were engaged with me and I controlled classes very well during the lessons.

I learned how to manage students online and how to make them all participate in the class. I learned how to know if the child did not understand and how to help him to understand.

Managing a class in online learning was reiterated by many participants as critical. One supervisor commented on the overall virtual experience and class management saying:

It was so organised and flowing. At first I was very pessimistic that no reasonable learning experiences can be attained by children in ECE online. But, the Microsoft Teams which was used in all schools was flawless. Children learnt and they enjoyed numerous online learning activities which include games which were selected for them to learn. Students did not have technical problems and trainee teachers managed to control children successfully.

Class management was listed as one of the key areas which trainee teachers developed throughout their virtual field experience. A trainee teacher said: "Overall, it was a good experience. The areas that I believe I have developed are, classroom management, time management, providing clear instruction, and differentiation." 


\section{Expanding the Repertoire of Teaching Strategies}

All trainee teachers and supervisors alluded to aspects of varying teaching strategies in online learning. A supervisor said:

I was amazed by the advanced level of digital competency which was demonstrated by our trainee teachers. They managed to use various technologies and teaching strategies which include auditory, visual, games and oral. The use of such various teaching strategies enabled them to cater for the diverse needs of young children in class.

Trainee teachers mainly differentiated instruction by using different teaching methods in order to enhance young children's online learning experiences. One trainee teacher said: "I learned to use a variety of methods to motivate students. For example, I used hang man, word finding and jigsaw puzzles." Similarly, another trainee teacher who used different teaching methods said:

Young children need something that grabs their attention when learning online so that they don't get bored. The teacher should vary the strategies used during teaching. For example, the lesson is presented in the form of a story, the lesson is presented in the form of a game, the lesson is presented in the form of a movie and the lesson is presented in the form of a contest. In these different ways, the child will pay attention to the online lesson and learn better.

Another trainee teacher said:

I was changing the layout of lessons by varying the use of strategies. Sometimes I would create a story for students, sometimes a game and sometimes a quiz. In general, I used to change the strategies used, but I was walking along with the same plan, in the beginning, with a review, then an explanation of the lesson and activities and finally, a final evaluation, so what changed in planning the lessons was the strategies used.

Trainee teachers believed that the use of multimedia resources will help children understand the topics better. This is why they were using different technologies and game-based applications to let children learn. A trainee teacher said she used "different types of applications, websites, online contents and programmes. I added some activities and games that are related to the content. This made learners more engaged and active." Similarly, another trainee teacher said: "To enhance student learning in the class, the teacher should use different educational videos during the lesson. The learner will hear and see different concepts related to their curriculum. Some topics are hard for students to learn easily, through different videos, students will be able to learn better." Some trainee teachers recommended that the best way to get young children involved in online learning is by teaching using different strategies which include playbased learning. One trainee teacher confirmed this saying:

Plan for a more play-based learning experience (using online games). Make the lesson's content more relatable by using real-world prompts. This way, the problem of having passive learning could be limited. Provide alternatives to screen time for younger students. Instead of their learning being entirely on-screen, encourage learning outdoors or indoors. For example, after the lesson, have the students explore their garden or create a habitat using tools around their house.

Students also differentiated assessments, as was stated by a trainee teacher:

It was a wonderful and successful experience. I used a lot of assessments and activities in order for the class not to be boring for students. For example, I have used fun activities to capture students' attention and I used some YouTube videos to make the classroom relevant to their daily life. I found these methods very interesting and beneficial as they benefited the students and they interacted and participated in the class with me.

\section{Discussion}

Students in this study had a positive perception about their virtual field experiences. Their main thoughts were primarily related to a technology integration plan, class management, and varying teaching strategies. This concurs with various studies conducted during the pandemic, in which it was established that technology integration and the use of varying teaching strategies are essential components for online learning (Albrahim, 2020; Gokuladas \& Sam, 2020; Kim, 2020). The theme of technology integration reasonates with the UAE context where the country envisions a more transformed education system; one which is inclusive and digitised. The COVID-19 pandemic has accelerated the country's plan to fully embed technology into the curriculum and it is highly probable that the country's education system may not be as it was before the pandemic. This agrees with the projection of the International Commission on the Futures of Education (2020) that when the current global pandemic of COVID-19 is over, education will not be the same as it was before. This challenges trainee teachers to acquire all the necessary skills to be able to implement effective pedagogical approaches in face-to-face or online classes.

The integration of technology and use of different teaching strategies made trainee teachers achieve their goals of 
teaching young children successfully online. The experience made trainee teachers develop a positive perception about virtual field experiences. This aligns with Bem's (1972) first claim in the theory of self-perception, that people develop positive attitudes, perceptions, and behaviour about something after they have observed and done it successfully. Trainee teachers reflected on their virtual field experiences, saw how successful it was, and began to recommend it. Similarly, trainee teachers in Turkey had positive perceptions about their successful online field experiences, as they managed to overcome technical problems and teach effectively (Ersin et al., 2020). It might be argued that the COVID-19 pandemic was a blessing in disguise in this regard. It has been a blessing in the sense that it offered trainee teachers a chance to learn more about technology, and to be creative, and it also offered "a unique chance to imagine more equitable societies and education systems" (Arnove, 2020, p. 43).

Integration of technology enabled trainee teachers to boost their self-efficacies related to online teaching, which made them have a positive mindset about teaching young children effectively while using different strategies. The use of different teaching strategies enhances students' learning experiences and enables learning outcomes to be achieved (Kim, 2020; Lestiyanawati \& Widyantoro, 2020). The use of different teaching strategies is critical in the online teaching of young children. Safitri et al. (2020) argue from the Indonesian context that online learning, which was implemented by teachers in early childhood, was not successful because they could not use different teaching strategies. This is why many parents in China did not support the initiative of online learning with young children (Dong et al., 2020).

Online learning in early childhood requires a collaborative approach to be applied, one where teachers and parents work together to manage classes and support children. Safitri et al. (2020) states that there is a need for active parental involvement in young children's online learning. Rasmitadila et al. (2020) contend that the parents' role in virtual classrooms is vital. Children need to be supported by helping them to set up the technologies to be used and by ensuring that they complete tasks given by the teacher. This aligns with Lathifah et al. (2020), who linked class management to successful teaching and learning online. Similarly, Kim (2020) reiterates that effective class management is tantamount to better teaching and learning.

\section{Implications}

This study has implications for educators, researchers, and policy makers. The COVID-19 pandemic presented unprecedented challenges in education and there is a lot that can be learnt from the experiences related to this study. The shift from regular face-to-face field experience to online is a practice that caught the whole world by surprise. This has implications for trainee teacher institutions, as they are challenged to have an urgent curriculum renewal in order to embed online learning modalities in all programmes. There is a need for trainee teachers to be afforded opportunities to practice online teaching and learning, and to perform virtual field experiences during the course of their training. This helps prepare them to be able to implement effective pedagogical practices using both methods of teaching (faceto-face and online learning). The other implication relates to teaching young children online. Although face-to-face is the best teaching strategy for children in early childhood, online learning takes precedence in a context where children cannot go to school because of a pandemic. Online learning for young children is better than no learning at all. This implies that policy makers should consider investing more in education by availing robust internet facilities and technological devices so that children learn to use them in schools and at home rather than waiting until schools are closed because of a pandemic.

\section{Strength and Limitation}

The strength of this paper lies on the fact that it focuses on a topic which is novel and it provides suggestions and implications which are practical and can be used to enhance students' virtual field experiences across the globe. The study was done using a federal university in Dubai. Further studies can use quantitative approaches and focus on private and public institutions. A limitation in this study is related to researcher bias. The researchers conducted the study using their own programme. Although it is noted as a limitation, it is essential to state that this did not compromise the quality of the research as high levels of professionalism and integrity were maintained throughout. Another limitation is the challenges faced in online teaching and learning in terms of infrastructure, technical issues, and limited access to internet sevices. Some students experience these challenges which may compromise their abilities to maximise online learning.

\section{Conclusion}

The purpose of this study was to examine perceptions of trainee teachers and faculty supervisors about online field experiences. The study concludes that although the COVID19 situation can be seen as a big misfortune which negatively affected teaching and learning across the globe, it had an unexpected benefit in the UAE context, as it provided a milestone of achievement towards attaining the country's goal of fully embedding technology in education. The COVID-19 situation accelerated technology integration into 
the curriculum, which was not only responsive to the global pandemic, but also the country's digital plan in education. Affording trainee teachers an opportunity to complete virtual field experiences benefited them as they graduated with knowledge and skills which allow them to be able to implement early childhood curriculum using two essential pedagogical approaches of face-to-face and online teaching. Although virtual field experiences were unprecedented, they offered internship students an opportunity to be creative and apply critical thinking skills to solve problems and manage young children's online learning experiences. This is an essential skill that is looming in the twenty-first century, a time in which online instructors should be able to think critically, solve problems and be able to cater for the diverse needs of children in online classes.

Funding No funding was received for conducting this study.

\section{Declarations}

Conflicts of Interest The authors have no conflicts of interest to declare that are relevant to the content of this article.

Ethical Approval The questionnaire and methodology for this study were approved by the Human Research Ethics committee of the current study university (Ethics approval number: ZU20_140_F).

Consent to Participate Informed consent was obtained from all individual participants included in the study.

\section{References}

Ak, Ş, \& Gökdaş, İ. (2021). Comparison of pre-Service teachers' teaching experiences in virtual classroom and face-to-face teaching environment. Turkish Online Journal of Qualitative Inquiry, $12(1), 1-23$.

Albrahim, F. A. (2020). Online teaching skills and competencies. TOJET: The Turkish Online Journal of Educational Technology, 19(1), 9-20.

Arnove, R. A. (2020). Imagining what education can be postCOVID-19. Prospects, 49, 43-46. https://doi.org/10.1007/ s11125-020-09474-1

Bem, D. J. (1972). Self-perception theory. In L. Berkowitz (Ed.), Advances in Experimental Social Psychology (pp. 1-62). Academic Press.

Brown, J. P. (2017). Teachers' perspectives of changes in their practice during a technology in mathematics education research project. Teaching and Teacher Education, 64, 52-62. https://doi.org/10. 1016/j.tate.2017.01.022

Cahapay, M. B. (2020). Rethinking education in the new normal postCOVID-19 era: A curriculum studies perspective. Aquademia. https://doi.org/10.29333/aquademia/8315

Chai, C. S., Koh, J. H., Ho, H. N., \& Tsai, C. C. (2017). Examining preservice teachers' perceived knowledge of TPACK and cyberwellness through structural equation modeling. Australasian Journal of Educational Technology, 28(6), 1000-1019. https://doi.org/10. 14742/ajet.807

Cohen, L., Manion, L., \& Morrison, K. (2017). Research methods in education (7th ed.). Routledge.

Creswell, J. W. (2012). Educational research: Planning, conducting, and evaluating quantitative and qualitative research. Pearson.

Creswell, J. W., \& Poth, C. N. (2018). Qualitative inquiry and research design: Choosing among five approaches. Sage.

Cruickshank, V., Pill, S., \& Mainsbridge, C. (2021). 'Just do some physical activity': Exploring experiences of teaching physical education online during COVID-19. Issues in Educational Research, 31(1), 76-93.

Dong, C., Cao, S., \& Li, H. (2020). Young children's online learning during COVID-19 pandemic: Chinese parents' beliefs and attitudes. Children and Youth Services Review, 118, 105440. https:// doi.org/10.1016/j.childyouth.2020.105440

Ersin, P., Atay, D., \& Meda, E. (2020). Boosting preservice teachers' competence and online teaching readiness through e-practicum during the COVID-19 outbreak. International Journal of TESOL Studies, 2(2), 112-124. https://doi.org/10.46451/ijts.2020.09.09

Fedynich, L. V. (2013). Teaching beyond the classroom walls: The pros and cons of cyber learning. Journal of Instructional Pedagogies. https://doi.org/10.19173/irrodl.v20i5.3985

Fiock, H. (2020). Designing a community of inquiry in online courses. The International Review of Research in Open and Distributed Learning, 21(1), 135-153.

Gokuladas, V., \& Sam, S. K. (2020). Challenges and responsibilities during school reopening post- COVID-19: A strategic approach. In I. Sahin \& M. Shelley (Eds.), Educational practices during the COVID-19 viral outbreak: International perspectives (pp. 199-220). ISTES Organization: Monument.

Gürkan, S. (2018). The effect of feedback on instructional behaviours of pre-service teacher education. Universal Journal of Educational Research, 6(5), 1084-1093.

Hixon, E., \& So, H. J. (2009). Technology's role in field experiences for preservice teacher training. International Forum of Educational Technology \& Society, 12(4), 294-304.

Hojeij, Z. \& Baroudi, S. (2021). Engaging pre-service teachers in virtual field experience during COVID-19. International Journal of Distance Education Technologies (IJDET), 19(3). In Press. International Commission on the Futures of Education 2020. Education in a post-COVID world: Nine ideas for public action. Paris: UNESCO.

Kim, J. (2020). Learning and teaching online during COVID 19: Experiences of student teachers in an early childhood education practicum. International Journal of Early Childhood, 52, 145-158. https://doi.org/10.1007/s13158-020-00272-6

Konca, A. S., Ozel, E., \& Zelyurt, H. (2016). Attitudes of preschool teachers towards using information and communication technologies (ICT). International Journal of Research in Education and Science, 2(1), 10-15.

Lapan, S. D., Quartaroli, M. T., \& Riemer, F. J. (2012). Introduction to qualitative research. In S. D. Lapan, M. T. Quartaroli, \& F. J. Riemer (Eds.), Qualitative research: An introduction to methods and designs (pp. 3-18). Josey-Bass.

Lathifah, Z. K., Helmanto, F., \& Maryani, N. (2020). The practice of effective classroom management in COVID-19 time. International Journal of Advanced Science and Technology, 29(7), 3263-3271.

Leonard, J., \& Guha, S. (2001). Education at the crossroads: Online teaching and students' perspectives on distance learning. Journal of Research on Technology in Education, 34(1), 51-58.

Lestiyanawati, R., \& Widyantoro, A. (2020). The strategies and problems faced by Indonesian teachers in conducting e-learning during COVID-19 outbreak. Journal of Culture, Literature, Linguistics and English Teaching, 2(1), 71-82. 
Lui, A. K., Choy, S. O., \& LI, S. C., \& CHEUNG, Y. H. . (2006). A study on the perception of students towards educational weblogs. Informatics in Education, 5(2), 245-266.

Miulesco, M. L. (2020). Digital media: Friend or foe? Preschool Teachers' Experiences on Learning and Teaching Online. Journal of Pedagogy. https://doi.org/10.26755/RevPed/2020.2/203

Moyo, N. (2020). COVID-19 and the future of practicum in teacher education in Zimbabwe: Rethinking the 'new normal' in quality assurance for teacher certification. Journal of Education for Teaching, 46(4), 536-545. https://doi.org/10.1080/02607476. 2020.1802702

Mohebi, L. (2018, November ). Investigating perceptions of pre-service teachers and instructors about TPACK capabilities of trainee teachers: an explanatory study among selected UAE universities. [Doctoral thesis, The British University in Dubai]. https://bspace. buid.ac.ae/handle/1234/1289.

Mohebi, L. \& Bailey, F. (2020). Exploring Bem's self-perception theory in an educational context. Encyclopaideia, doi:1825-8670/9891

National Agenda. (2018). First-Rate education system. From UAE Vision 2021: https://www.vision2021.ae/en/national-agenda2021/list/first-rate-circle.

Rasmitadila, A., \& R. R., Rachmadtullah, R., Samsudin, A., Syaodih, E., Nurtanto, M., \& Tambunan, A. R. . (2020). The perceptions of primary school teachers of online learning during the COVID-19 pandemic period: A case study in Indonesia. Journal of Ethnic and Cultural Studies, 7(2), 90-109. https://doi.org/10.29333/ ejecs $/ 388$
Safitri, A. M., Mustiningsih, Timan, A., Dwi Kurnianing Ratri, G. F., Argadinata, H., \& Fahmi, A. K. 2020. Curriculum management strategies as efforts to improve the effectiveness of early childhood learning during the COVID-19 pandemic (2020). 1st International Conference On Information Technology And Education (ICITE 2020). Indonesia: Universitas Negeri Malang. pp. 326-331

Shiburi, M. (2021). The development of ICT in education. Retrieved January 18, 2021 from Sutori: https://www.sutori.com/story/thedevelopment-of-ict-in-education-policy-in-ghana--Dx4ywswJYf bjBNCn5GTwLZac.

Valente, D. (2020). Supporting every teacher: teaching children online, avoid 'edutainment' but don't lose the fizz! From world of better learning: https://www.cambridge.org/elt/blog/2020/03/18/teach ing-children-online/.

Yin, R. K. (2018). Case study research and applications: Designs and methods. Sage.

York, J. (2020). 8 ways to make lessons fun and engaging in an online classroom. From teachaway: https://www.teachaway.com/blog/ increase-engagement-in-online-classroom.

Publisher's Note Springer Nature remains neutral with regard to jurisdictional claims in published maps and institutional affiliations. 